\title{
LINGUOPOETICS OF CORPORALITY IN LITERARY TEXTS OF ENGLISH MODERNISM AND POSTMODERISM Iryna Galutskikh (Zaporizhzhya, Ukraine)
}

I.A. Galutskikh. Linguopoetics of corporality in literary texts of English modernism and postmoderism. The article focuses on the study of linguistic manifestations of corporality in literary texts of English modernism and postmodernism, which envisages the analysis of literary corporality as a linguopoetic category. As a product of cognition and literary conceptualization of human bodily experience in the dialectic unity of its somatic-physiological, sensory, psychic, and mental facets, this category is formed in compliance with the author's aesthetic purport in the context of an epoch, being manifested in literary text through its verbal, imagistic, and narrative semiotic means. Given the assumption that a literary text is a multilevel verbal unity, comprising a complicated system of codes, the research applies a cognitive-semiotic approach to the analysis of literary corporality. Such an approach fostered revealing the specificity of multidimensional textual representation of literary corporality, including a fictionalized body as a narrative construal, with regard to a set of mental structures relevant to literary interpretation of corporality. The authorial construal of fictionalized body incorporates three dimensions: conceptual, narrative-semiotic, and verbal. This construal is represented in the narrative by its three varieties: sensory-emotional, eroticized, and socialized bodies. They are marked by narrative patterns which specify linguopoetic features of corporality in literary texts of English modernism and postmodernism, related to its conceptual, narrative-semiotic, and verbal manifestations.

Keywords: cognitive poetics, cognitive semiotics, construal, constructing, linguopoetics, linguopoetic category, modernism, fictionalized body, postmodernism, literary text, literary corporality.

І.А. Галуцьких. Лінгвопоетика тілесності в художніх текстах англійського модернізму та постмодернізму. Стаття присвячена вивченню мовних проявів тілесності в художніх текстах англійського модернізму та постмодернізму, що передбачає аналіз художньої тілесності як лінгвопоетичної категорії. Як продукт пізнання та літературної концептуалізації людського тілесного досвіду в діалектичній єдності його соматико-фізіологічного, сенсорного, психічного і ментального аспектів, ця категорія формується відповідно до естетично спрямованої діяльності автора в контексті епохи, яка проявляється в літературному тексті через його словесні, образні та наративно-семіотичні засоби. 3 огляду на розуміння художнього тексту як багаторівневого вербального утворення, що охоплює складну систему кодів, дослідження застосовує когнітивно-семіотичний підхід до аналізу художньої телесності. Такий підхід сприяв виявленню зв'язків багатовимірного текстового подання художньої тілесності, включаючи охудожнене тіло як наративний конструкт, із комплексом ментальних структур, пов'язаних 3 художнім відображенням тілесності. Авторське конструювання охудожненого тіла включає три виміри: концептуальний, наративно-семіотичний та словесний. Цей конструкт представлений в наративі трьома різновидами: сенсорно-емоційним, еротизованим та соціалізованим тілом. Вони марковані наративними моделями, які специфікують лінгвопоетичні особливості тілесності в художніх текстах англійського модернізму та постмодернізму, пов'язані 3 його концептуальними, наративно-семіотичними та словесними проявами.

Ключові слова: когнітивна поетика, когнітивна семіотика, конструкт, конструювання, лінгвопоетика, лінгвопоетологічна категорія, модернізм, охудожнене тіло, постмодернізм, художній текст, художня тілесність.

И.А. Галуцких. Лингвопоетика телесности в художественных текстах английского модернизма и постмодернизма. Статья посвящена изучению языковых проявлений телесности в

(C) Galutskikh I.A., 2018 
художественных текстах английского модернизма и постмодернизма, что предусматривает анализ художественной телесности как лингвопоэтической категории. Как продукт познания и художественной концептуализации человеческого телесного опыта в диалектическом единстве его соматико-физиологического, сенсорного, психического и ментального аспектов, эта категория формируется в соответствии с эстетически направленной деятельностью автора в контексте эпохи, что проявляется в художественном тексте через его словесные, образные и нарративно-семиотические средства. Учитывая понимание художественного текста как многоуровневого вербального образования, охватывающего сложную систему кодов, в исследовании применяется когнитивносемиотический подход к анализу художественной телесности. Такой подход способствовал выявлению связей многомерного текстового представления художественной телесности, включая охудожествленного тела как нарративный конструкт, с комплексом ментальных структур, связанных с художественным отображением телесности. Авторское конструирование охудожествленного тела включает три измерения: концептуальное, нарративно-семиотическое и словесное. Этот конструкт представлен в нарративе тремя разновидностями: сенсорно-эмоциональным, эротизированным и социализированным телом. Они маркированы нарративными моделями, которые специфицируют лингвопоэтологические особенности телесности в художественных текстах английского модернизма и постмодернизма, связанные с его концептуальными, нарративно-семиотическими и словесными проявлениями.

Ключевые слова: когнитивная поэтика, когнитивная семиотика, конструкт, конструирование, лингвопоэтика, лингвопоэтологическая категория, модернизм, охудожествленное тело, постмодернизм, художественный текст, художественная телесность.

\section{Introduction}

The meaning of corporality in the humanities has always been complicated since the term has been applied in multidisciplinary context. This caused ambiguity and stipulated a wide range of its interpretations. The latter fall into three groups based on:

1) philosophic interpretation of corporality where the term "corporality" is defined within ontological approach as substantial, special and temporal being of body (Frolova 2000; Krutkin 1997; Ostry 2007), phenomenological approach (where corporality is treated as somato-physiological and psycho-emotional entity) (Merleau-Ponti 1999; Podoroga 1995) and epistemological approach as interrelation of physiological and mental aspects of being (Kniazeva 2009);

2) sociocultural understanding of corporality as body being transformed under the influence of sociocultural factors (Bykhovskaya 2000; Korietskaya 2006) that comprises semiotic vision of corporality as a code system (Verbytska 2009);

3) philological interpretation with linguistic (Korotun 2002; Materynska 2009; Seryakova 2012; Zalevska 2005), literary (Gundorova 2010; Khrabrova 2001; Kulichikhina 2012; Poltarobatko 2009) and linguopoetic (Nasalevich 2003; Skachkov 2007) approaches, including interdisciplinary branches - cognitive linguistic (Klievtsova 2007; Marmaridou 2011; Stetsiura 2010), cognitive poetic (Ibarretxe-Antunano 2002; Kövecses 2002), cognitive semiotic ones (Violi 2010; Ziemke 2003; Zlatev 2008).

Linguistic studies of corporality manifested in language and text by nominations of human body and bodily experience have traditionally been limited to the analysis of somatic lexicon as a system formation (Alieva 2010; Zamoiska 2004) having communicative (Soloschuk 2006), cultural (Gudkov, Kovshova 2007), semiotic (Arkadiev, Kreidlin et al. 2008; Gudkov, Kovshova 2007; Sieriakova 2012) and conceptual significance as experiential basis for the processes of conceptualization and categorization (Gallagher 2006; Lakoff \& Johnson 1980; Ziemke 2003; Zlatev 2008). Literary studies have focused on the aspects of corporality actualized in literary texts of different genres and epochs being pronouncedly accentuated in modernism and postmodernism literature (Poltarobatko 2009; Shteinbuk 2006; Shtokhman 2008). Linguopoetic research of corporality comprises the analysis of somatic vocabulary connotative meaning (Yeliferova 2007), sensory concepts (Bogumil 1988; Mescheriakova 2011; Pierminova 2003; Starostina 2009; Vorobyova 
2012) and their role in the imagery formation of literary texts, stylistic aspects of characterisation (Nasalevich 2003; Skachkov 2007; Tataru 2007).

The integration of all approaches to corporality suggested in the discourse of the humanities enabled its complex interpretation as a category and became the basis for its understanding as a linguopoetic category.

The core of the category is the concept of human body which acquires under the impact of sociocultural factors a series of properties in addition to initial ones, thus, set of properties of the category "corporality" comprises two groups of parameters: 1) ontological as basic ones manifested in somato-physiological, sensory, psycho-emotional and mental characteristics, and 2) sociocultural ones, among them being semiotic nature implying gender, eroticized and transformation qualities.

The abovementioned interpretation of corporality as an ontological and sociocultural category envisages the understanding of literary corporality as a linguopoetic category being the object of this research in its verbal and narrative dimensions in literary texts of English modernism and postmodernism.

The research proceeds from interpreting this category in combination of its logical and philosophical understanding as a denotative and referential phenomenon that in literary text functions as an entity having content and expression sides (Turayeva 1979), as well as of its cognitive and semantic interpretation resultant from the process of categorization (Rosch 1980).

Literary corporality as a linguopoetic category is a product of cognition and literary conceptualization of human bodily experience in the dialectic unity of its somatic-physiological, sensory, spiritual (psychic), and mental aspects. This category is formed in compliance with the author's aesthetic intention in the context of a certain epoch, being actualized in literary text with the help of verbal and narrative-semiotic means.

The subject of my research is linguopoetics of corporality as a set of dominant lingual properties of a literary text employed by an author for realization of an artistic idea in view of vision of corporality specific for author's style and literary trend.

Given the assumption that a literary text is a multi-level verbal formation comprising a complicated system of codes (Barthes 1989), the research applies a cognitive-semiotic approach to the analysis of literary corporality as a linguopoetic category, using as the empirical material a corpus of English modernism (V. Woolf, D.H. Lawrence) and postmodernism (J. Fowles, P. Ackroyd, J. Winterson, I. Vaugh, S. Rushdie, F. Weldon, A. Burgess) literary texts.

This approach fostered reaching the aim of this research - revealing the specificity of multidimensional textual representation of literary corporality with regard to the verbal and narrativesemiotic dimensions of fictionalized body as a construal. It also allowed to discover interconnections of literary text semiotic structures and mental structures, relevant to literary interpretation of corporality.

\section{Method}

A cognitive-semiotic approach to the analysis of literary corporality in English modernism and postmodernism applied in this research comprises three stages of the procedure.

The first stage of analysis implies identification of the inventory of textual signals by means of their selection from lexicographic sources, systematization and description of language means of English nominating Homo somaticos, integrating its somatic, physiological, sensory, psychicemotional and mental aspects.

Key verbal markers of corporality in English are the following lexical means:

- corporality (corporeality, corporeity), embodiment and carnality as well as constituents of its synonymic group: fleshliness, sensitivity, sensitiveness, sensuality, sexuality, libido, lustfulness, voluptuousness, lechery, prurience (CCT 1997);

- body as the most generic term with the highest index of frequency (327 according to DFEL as well as constituents of its synonymic group: build, figure, flesh, form, frame, physique, shape, 
torso, trunk, cadaver, carcass, corpse, deadbody, relics, remains, stiff (CCT 1997) and their derivatives: bodiless, bodies, bodily, embody, embodiment, body (v), body-built, body-line, bodycentered, bodyguard, bodywork, bodycavity, bodyfluid, bodycell, bodycheck, bodyclothes, bodyheat, bodyimage (WTNIDEL 1993) etc., with the semes 'pertinent / characteristic of the body, 'similar to the body';

- structural and semantic derivatives of the constituents of synonymic groups of the abovementioned lexical means with the semes 'somato-physiological': anatomical, bodily, carnal, corporal, corporeal, fleshly, physical, somatic (CCT 1997); 'sensory: sensory, sensitive, sensorimotor, perceptive (CCT 1997), 'carnal, sensual, sexual': carnal, fleshly, erotic, erogenous, lecherous, lascivious, lewd, libidinous, lustful, prurient, licentious, sensual, sensuous, sexual, voluptuous, sensory (CCT 1997);

- verbs nominating the process of embodiment: embody, incarnate, incorporate, corporealize, carnalize, carnify (CCT 1997).

Selected linguistic (lexical, phrasal, syntactic, etc.) signals of corporality in literary texts of English modernism and postmodernism are taxonomized in accordance with various criteria:

1) according to the type of their thematic reference to the following semantic groups:

- "Somatics and physiology", that falls into:

- "Homo somaticos (external)" including "Parts of body" (head, neck, trunk, thorax, chest, breast, abdomen, dorsum, back, pelvis, arms, hands, fingers, legs, feet, toes, buttocks, thighs, elbows, shins, heels, wrists), "Face and its parts" (face, nose, forehead, eyes, eyebrows, lips, tongue, beard, chin, cheek, eyelid, eye-lashes), "Foramen" (nostrils, mouth, cavity, eyesocket, auricle, anus), "Body lines and heterogeneous somatic objects" (waist, loins, wrinkles, scar, dimples, acne, freckles, armpits, mole, birthmark, rash);

- "Homo somaticos (internal structure and functioning)" including "Organs and their systems" (organs, entrails, viscera, heart, blood vessels, veins, capillaries, arteries, aorta, blood circulation, digestive system, glands, stomach, intestine, liver, gastrointestinal tract, pharynx, spleen, pancreas, gallbladder, appendix), "Cellular structure of the body" (gene, mitosis, neurons, DNA, cell, erythrocytes, lymphocytes, leukocytes), "Physiological liquids and substances" (blood, plasma, lymph, phlegm, mucus, bile, sweat, tears, urine, saliva, semen, gastric juice, breast milk, hormone, adrenaline, amino), "Physiological states and processes" - normative (metabolism, homeostasis, peristalsis, perspiration, secretion, sleep, hunger, thirst, breathing, digestion, pregnancy, ovulation) and pathological (disease, immunodeficiency, pathology, illness, lethargy, agony, swelling, indigestion, insomnia, inflammation, tumour, metastasis, cancer, flu, pneumonia, fever, pain, bruise), "Physiologic ontogenesis stages" (embryo, foetus, puberty, baby, oldness, old age, life, death);

- "External body qualities and body behaviour" characterising such parameters of the body as "size", "weight" (corpulence, fatness, obesity, tall, slim), age (young, old), nation and race (Europeoid, coloured, Roman nose), aesthetic features (tanned, pale, complexion, handsome), gender qualities (manlike, masculine, female, womanly, feminine, sex), "bodily" actions (smile, frown, kiss, mimics, gesture);

- "Sensory and organs of perception" (touch, palpate, vision, olfaction, hearing, taste);

2) according to quantitative distribution - singular (eye), dual (organ of vision, organ of sight) and multiple - groups of signals;

3) according to the type of nomination - denotative (head) and connotative (e.g. colloquial equivalents of head-dome, top, melon, nut, skull, bean, etc. meaning "head");

4) according to the textual scope - global, local and localized found out and interacting within the whole text, its fragment or separate component (Vorobyova 1993).

Selected linguistic signals serve for identification of text fragments in which literary corporality is actualized as well as in the course of reconstruction of conceptual tropes and narrative patterns. 
The second stage of research is the analysis of its imagery and symbolic aspects by means of reconstruction of conceptual tropes which demonstrate the way the image embodies vision of human body and bodily experience in verbal form.

The stages of reconstruction of conceptual tropes on the text fragment of P. Ackroyd's "London: The Biography": Here might be found the 'heart of London' beating warm. The byways of the city resemble thin veins and its parks are like lungs (Ackroyd LB, p. 2-3) are the following:

1) identification of verbal imagery means including corporality nominations (heart, lungs) and selection of corresponding text fragments;

2) identification of the type of interrelation (comparing, contrasting, etc.) between contiguous objects, where by means of conjunctions like (its parks are like lungs), as (London as a human body), as if (stones and cobbles [...] look as if they are bleeding), as well as lexical unit resemble (byways of the city resemble thin veins), iconic principle of distance comes into work due to maximum proximity of constituents (Dirven \& Verspoor 2004);

3) definition of source and target domains of imagery conceptualization - something that is described (CITY) and the means used to describe it (HUMAN BODY), with the help of their verbal nominations (London, byways, parks and veins, heart, heart);

4) elaboration of typology of imagery of corporality in accordance with the type of cognitive operation beneath: analogy (byways resemble veins, parks like lungs), association (her fear made her heart beat increase), contrast (bitter sweetness, pleasure close to pain, frozen cheek burned me), specification / characterisation (R. Langacker 1990) (ruined body, deformed body), etc.;

5) systematisation of the results obtained by means of stating the range (one referent - several correlates) and scope (one correlate - several referents) of conceptual metaphors (Kövecses 2002);

6) quantitative analysis for revealing the imagery priorities of a text, cognitive style of a writer, literary trend - modernism or postmodernism in view of the vision of corporality.

The third stage of the analysis of literary corporality is reconstruction of its narrative aspect, i.e. specific features of body experience narration in a literary text with the help of narrative patterns - schemes of narration of human body or its properties.

The algorithm of the analysis comprised the following steps:

1) identification of narrative signals of verbal and/or adjectival type that respectively designate body actions or events (kiss breast, body melts, body burns, touch skin, smell sweet, feel agony), or nominate properties or conditions of a body (wounded in the arm, naked body, dissolved body, pierced heart, broken heart);

2) classification of narrative signals in accordance with their semantics and elaboration of typology of fictionalized body in literary texts of English modernism and postmodernism. Its types embrace sensory-emotional body (taste sweet, feel pain, suffer headache, tremble with cold, frozen blood), eroticized body (lie naked, lick lips, kiss breast, entity of bodies) and socialized body (bodies communicate, well-trained body, stigma burnt on flesh, people without faces, skeleton of social habit);

3) singling out narrative patterns - schemes of narration of two main types - designating the vector of corporality transformations (e.g. "eroticizing", "socializing", "psychologizing", with oppositions "natural" vs "unnatural" within each of them, and type of corporality transformations characterising body changes in literary semantics according to their intensity: "modification", "deviation", "deformation", "destruction";

4) systematisation of the results obtained and quantitative analysis for revealing the imagery priorities of a text, cognitive style of a writer, literary trend (modernism or postmodernism) in view of the vision of corporality.

The narrative code constituents that embrace compositional and narrative signals of literary corporality, which form respective narrative patterns, contribute to the manifestation of fictionalized body as a narrative construal. 


\section{Results and Discussion}

In terms of cognitive-semiotic approach, literary corporality is viewed as multi-level formation integrating linguistic (represented by verbal and narrative codes) and cognitive structures. Interrelation of two types of codes in a literary text is based on the following factors: 1) verbal code constituents serve as denotative and connotative means of corporality nomination; 2) narrative codes of literary corporality contribute to its narrative embodiment in a succession of actions and events of the body within a single temporal and spatial image or plot of a literary text creating the vision of corporality.

Linguistic aspects of literary corporality in entity of verbal and narrative codes correlate with its cognitive dimension forming entire cognitive-semiotic space of literary corporality.

The research introduces a cognitive-semiotic interpretation of literary corporality as a model which reveals the correlation of its cognitive dimension comprising the prototypic vision of corporality as a material phenomenon and semiotic dimension related to verbal and discursive as well as narrative manifestations of corporality in a literary text as a multi-layered semiotic system.

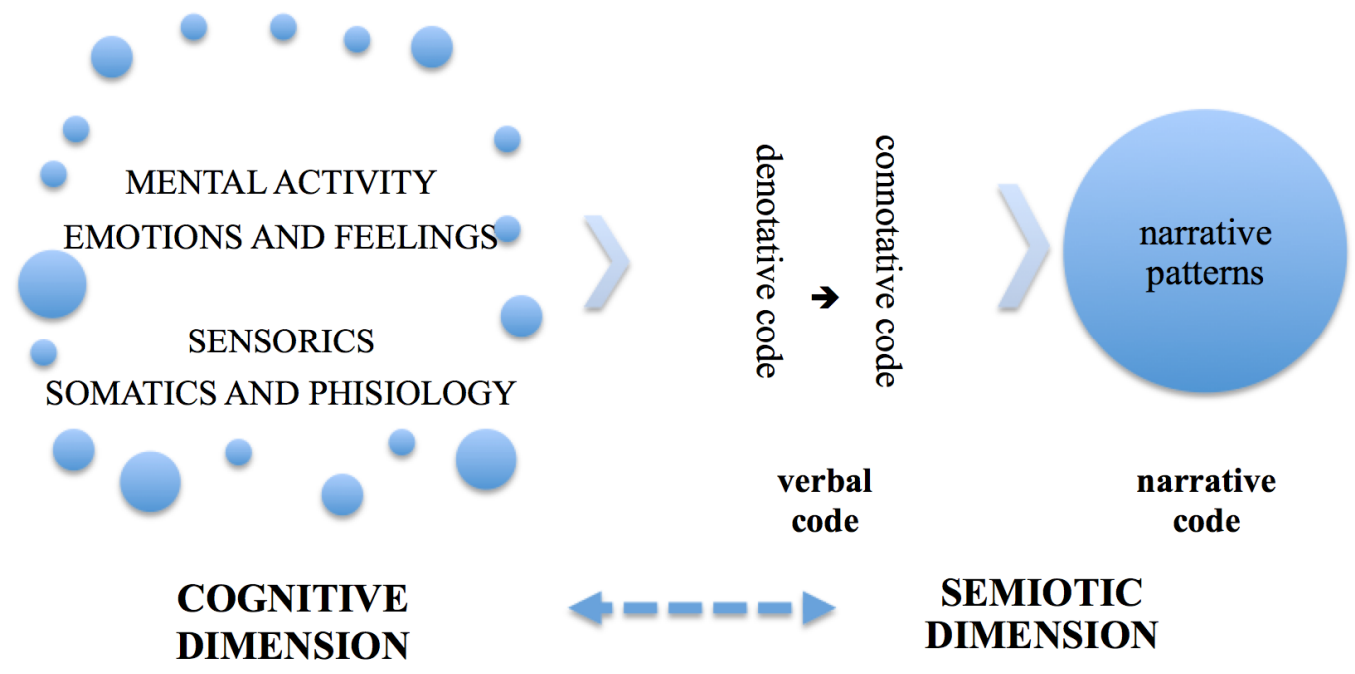

Figure 1 . The model of literary corporality as a linguopoetic category

The cognitive dimension of literary corporality as a category comprises the conception of human body and bodily experience in the dialectic unity of their somato-physiological, sensory, psycho-emotional, and mental facets as its ontological background, while integrating four interrelated thematic domains SOMATICS AND PHYSIOLOGY, SENSORY PERCEPTION, EMOTIONS AND FEELINGS, MENTAL ACTIVITY.

The semiotic dimension of literary corporality in its verbal and narrative planes embraces a multitude of multilevel linguistic means as well as compositional and narrative devices that are employed as textual signals of this category.

According to the type of nomination the constituents of verbal code of literary corporality fall into denotative and connotative. The first group includes nominations of somato-physiological aspects of human body as a referent (She registered the warm tones of the two female figures [...] level-eyed and barefooted (Fowles ET: 3 ). The latter includes imagery means of literary corporality where human body becomes target domain - I would call her nipples twin domes of her body's temple (Lodge T: 178) or source domain of conceptualization - the house resembled the torso of a man rearing up, while his arms still lay spread [...] it was as if I were about to enter a human body (Ackroyd HDD: 3). The second group includes textual symbols as well (My nose: elephantine as the trunk of Ganesh, have been a superlative breather; a smeller without an answer (Rushdie MC: 31), Doctor Aziz's nose - comparable only to the trunk of the elephant-headed god Ganesh- 
established incontrovertibly his right to be a patriarch (ibid: 9) and symbolized imagery (Twisted shells with red lips ornamented the mantelpiece (Woolf VO: 9).

The narrative level of literary corporality comprises narrative means that form narrative code realized by narrative patterns. Systematization of narrative patterns recurrent in literary text enabled the identification of narrative varieties of fictionalized body. Their reconstruction revealed specific features of literary corporality as a linguopoetic category in its narrative-semiotic manifestations in English literary texts of modernism and postmodernism in their juxtaposition.

A fictionalized body is interpreted as a narrative construal that incorporates cognitive, narrativesemiotic, and verbal levels, while being represented in the narrative by its three varieties: sensoryemotional, eroticized and socialized bodies.

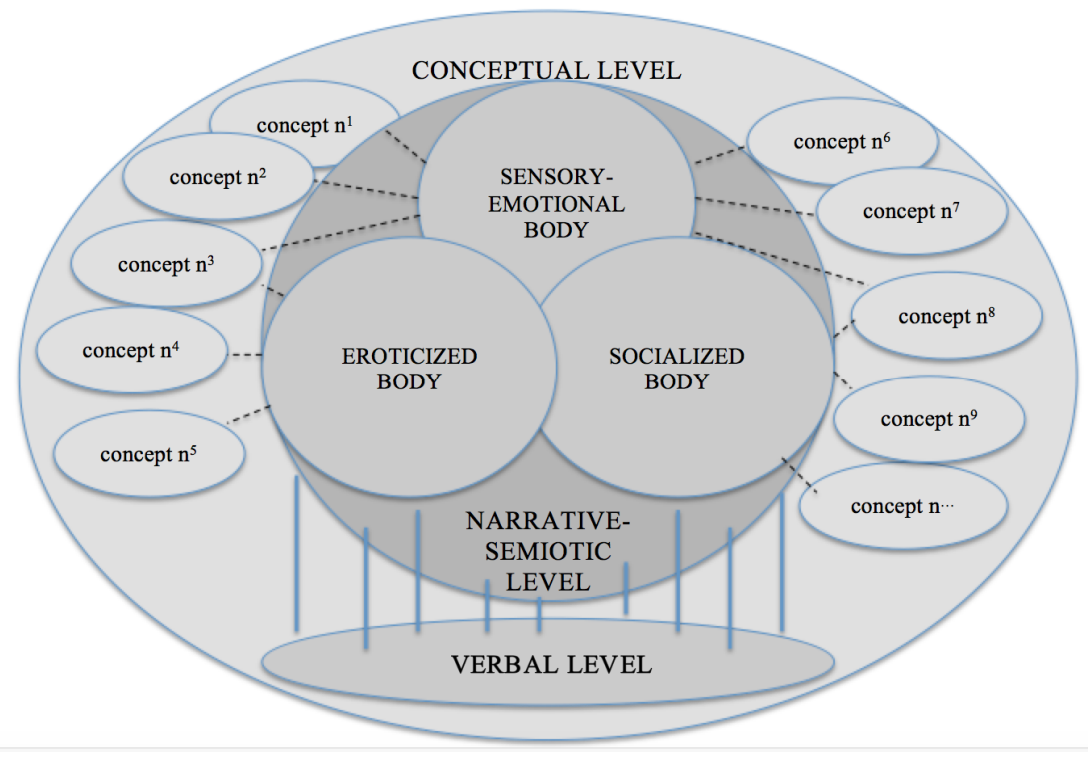

Figure 2. Fictionalized body as a construal

Their construction by the author involves such narrative patterns as "psychologizing / pathologizing", "eroticizing", or "socializing", respectively. Each above-mentioned narrative variety of fictionalized body finds its manifestation through the corporality transformations ranging according to the scale of "modification" - "deviation" - "deformation" - "destruction", which occur in the narrative structure of literary text in its referential, imagistic and/or symbolic planes. The vector and type of fictionalized body transformations specify the features of linguopoetics of corporality in the analysed texts of English modernism and postmodernism, thus characterizing the modernist and postmodernist visions of corporality manifested in them both in cognitive and verbal facets, thus shaping the narrative varieties of fictionalized body.

Specific features of sensory-emotional body construction consist in the narrative "deformation" of fictionalized body and its reconceptualization according to the model SENSORY-EMOTIONAL BODY IS A DEFORMED BODY in the English modernism prose, whereas in the literary texts of English postmodernism its narrative "destruction" according to the conceptual model SENSORY-EMOTIONAL BODY IS A RUINED BODY is observed. Narrativisation of the fictionalized body takes place against the background of its "psychologizing" in the English modernistic texts under study and "psychologizing / pathologizing" - in the literary texts of English postmodernism.

Narrative pattern "psychologizing" implies imagery conceptualization of corporeal phenomena as emotional and psychic states of a human: A great pang of fear went through his heart (Lawrence EME: 17), where conceptual metonymy SHARP PAIN IN THE HEART stands for FEAR is accompanied with the metaphor SHARP PAIN IS PIERCING, and This hole in my heart is in the shape of you and no-one else can fit it (Winterson WB: 155), where conceptual metaphor 
PSYCHOLOGICAL LOSS IS A HOLE IN ONE'S HEART, based on conventional conceptual metonymy HEART stands for EMOTIONAL STATE OF A PERSON, in its verbal facet serves as a textual reference to the lost love and suffering.

Textual signals of human body imagery conceptualization in literary verbalisation of emotions and feelings are lexical units body, flesh, parts of body, organs and physiological liquids (heart, blood, breast, bosom, bowels, bones, womb, throat, head), physiological processes and phenomena (bleeding, lethargy, agony, intoxication, bruise, pain, death, suffocation, spasm, body paralysis, soberness), sensory of the body (senselessness, torment, taste, physical pain, heat in the body), corporeal states (body shuddering, trembling body, body tension), physical qualities of the body as weight, size (heavy body, light body, small body), bodily actions and body position in space (swallowing, embracing, queer movements).

Such means of verbalisation sustain the idea of close integration of conceptual spaces of corporeal, psycho-emotional and mental experiences of a human being. Merging of domains HUMAN BODY and EMOTIONS / FEELINGS observed in literary texts of English postmodernism is accompanied by semiotization on the narrative level implying imagery conceptualization of HUMAN BODY as A SIGN: I took her two hands to my mouth and kissed each slowly so that I could memorize the shape of her knuckles (Winterson WB: 50), where tactile contact is viewed as perception of information (TOUCH stands for MEMORIZING).

Narrative pattern "pathologizing", specific of literary corporality of English postmodernism, implies reference to pathologies of the body and serves for verbalisation and narrativisation of ill body:

Cancer treatment is brutal and toxic. Her spleen started to enlarge, she had splenic irradiation or even a splenectomy, she would be badly anaemic, bruising and bleeding, in pain, constipated, vomiting and nauseous, it would contribute to failure of her bone marrow. There is no cure for lymphocytic leukaemia (Winterson WB: 102).

The role of textual signals of pathological (ill) body in this text fragment is played by nominations of illness (cancer, lymphocytic leukaemia) and of bodily pathological states as its consequences (spleen enlarging, splenic irradiation, splenectomy, anaemic, bruising, bleeding, in pain, constipated, vomiting, nauseous, failure of bone marrow).

In J. Winterson's novel "Written on the Body", ill body becomes target domain of imagery conceptualisation as well, e.g. CANCER is metaphorically described as BETRAYAL OF THE BODY, while THE BODY HAVING CANCER - as THE BODY THAT BETRAYED ITSELF: Cancer is an unpredictable condition. It is the body turning upon itself (Winterson WB: 105), or as a VICTIM OF INTERNAL REBELLION: but the white T-cells have turned bandit. They don't obey the rules. They are the enemies on the inside. The security forces have rebelled (ibid: 115), where defending forces of the organism itself become the members of the coup depicted on the background of corresponding physiological processes.

Realization of narrative patterns "psychologizing" and "pathologizing" of the body in literary texts of English modernism and postmodernism corresponds to certain types of transformations of corporality accompanied by actualisation of narrative patterns "deformation" and "destruction".

In literary texts of English modernism psychologising of fictionalized body is accompanied with its "deformation" and conceptualisation according to the model of characterisation SENSORYEMOTIONAL BODY IS A DEFORMED BODY. On the level of verbal code it is described as an object having lost its integrity, consistence, size, etc. and, eventually, experiencing pain (e.g. melting body, physical wreckage, rigid body, shrunk body, heavy body, bleeding heart, lethargy, spasm, agony, body paralysis) or having potential of possible deformation that is implied by means of placing the character in the situation concerned with it (e.g. heat / coldness in the body, halt of heart, the rise of blood pressure, suffocation, intoxication). 
The narrative pattern "deformation" is actualized in fragments of literary modernistic texts, where imagery transformations concern:

- body as a whole (32\%), usually by means of narrativisation of conceptual metonymies:

- RIGID BODY stands for INDIFFERENCE: over them both came paralyzing blankness of feeling [...] as the mind turns rigid, so does the body; stark, statuesque (Woolf TA: 143),

- SHRUNK BODY stands for UNCERTAINTY: She felt as if her body had shrunk; it had grown small (Woolf LL: 71);

- parts of body (27\%) as, e.g. in metaphtonymies with heart as a component: Our hearts melted away, we thought to die (Lawrence FSG: 89), where the metaphor HEART IS A MELTING SUBSTANCE becomes a correlate for FEAR, and When Egbert saw his little girl limping, his heart again hardened with chagrin, like steel that is tempered (Lawrence EME: 20), where the metaphor HEART IS A HARDENED SUBSTANCE stands for GRIEF;

- physiological liquids that metaphorically undergo chemical changes (13\%): The officer sat [...] all his blood seemed to be corroding (Lawrence PO: 6), where CORRODED BLOOD stands for FEAR.

The construction of sensory-emotional fictionalized body by means of its psychologising in literary texts of English postmodernism is accompanied by its "destruction" according to the conceptual model of characterisation SENSORY-EMOTIONAL BODY IS A RUINED BODY. Among textual signals of this type the word body and constituents of its synonymic group - flesh, physique are the most frequent. In $87 \%$ of text fragments of postmodernist literary prose we observe metaphoric images of "ruined body" with violated structure, consistency or integrity (e.g. softened body, weakened body, ill body, dead body, enlarged body, wounded body, bleeding body). Noticeably, predominantly (in $77 \%$ of text fragments) they are the imagery correlates of positive feelings, e.g. in the course of imagery conceptualization of high body temperature as body in passion: We made love [...] those brief hours were offerings to a god who would not be appeased by burning flesh (Winterson WB: 20), When ever you think you are falling in love, remember that ring is molten hot and will burn you through and through (ibid: 31-32). The verbal markers of conceptual metaphtonymy BODY IS A BURNING FIRE stands for PASSION, DESIRE are burning flesh or the phrase will burn you through and through that explicitly or implicitly emphasize destructive influence of emotional state on the body.

Allusions as signs of intertextuality are specific features of literary texts of English postmodernism observed in the imagery interpretation of body in passion:

"...the steady flame she offered might be fed ... if Louise were a volcano then I might be Pompeii (Winterson WB: 49).

Metaphorical interpretation touches the bodies of both lovers: one is conceptualized by means of associating image-metaphor BODY-FIRE with metaphorical correlate VOLCANO, the other - by means of comparing image-metaphor BODY IN FIRE to POMPEII. This image is based on metaphor of parabolic type (Turner 1998), where narrative mapping is applied - the projection of the famous historical event story (ruining of Old Roman city of Pompeii that was burnt during Vesuvius eruption in 79 AD) on the meaning of the literary image (Bieliekhova 2002).

Cognitive processes involved into image formation in the course of sensory-emotional body construction are common for modernistic and postmodernistic literary texts and embrace analogous $-a$ metaphor (BODY IS POMPEII), associative - a metonymy (HIGH RATE OF HEART BEAT stands for FEAR), as well as metaphtonymic means as their combination (RIGID BODY stands for INDIFFERENCE).

Narrative patterns actualized in analysed texts envisage the typology of sensory-emotional fictionalized body which is depicted in modernistic prose as unnatural, psychologized, semiotic and deformed whereas in postmodernistic - as unnatural, psychologized, semiotic, destructed and pathologized. 
The quantitative analysis demonstrated more pronounced significance of sensory aspects of the body - tactile, visual, gustatory, olfactory and audial, $87 \%$ of spectre being associated with unpleasant and painful emotional experience of literary characters.

Literary texts of English modernism tend to construct eroticized fictionalized body by means of its narrative "naturalizing / romanticizing" and its conceptualization according to the model HUMAN BODY IS A NATURAL PHENOMENON Or NATURAL PHENOMENON / ABSTRACT PHENOMENON / ARTEFACT IS A HUMAN BODY, having narrative "modification" of eroticized body as its background. Eroticizing of postmodernistic body relies on its attributing narrative "artificiality" in terms of the conceptual metaphor HUMAN BODY IS AN ARTEFACT / ARTIFICIAL PHENOMENON / SIGN, and its "deviation" by means of the conceptual model EROTICIZED BODY IS A DEVIANT / PERVERSE BODY.

In literary texts of English modernism, "naturalizing / romanticizing" of the body corresponds to the overall tone of modernistic vision of eroticized body and is accompanied by its imagery conceptualization by means of metaphors:

- HUMAN BODY IS A NATURAL PHENOMENON / LANDSCAPE, actualized in $93 \%$ of text fragments, with human body as a target domain: Her breasts were pear-shaped [...] unripe, a little bitter (Lawrence LCL: 77), where breasts are conceptualized as pears on the basis of similar outlooks; or the most beautiful part of her [...] the haunches from the socket of the back and the buttocks. Like hillocks of sand (ibid: 75), where women's haunches, buttocks are compared to hillocks of sand;

- NATURAL PHENOMENON / LANDSCAPE IS A HUMAN BODY, actualized in $63 \%$ of text fragments in which body parts serve as source domains: like the dance of olive trees and their myriad-tongued grey leaves (Woolf W: 163), where the form of leaves is compared to a tongue (myriad-tongued leaves), or in the following fragments, where shell edge and river banks are metaphorically depicted as similar to lips (shells with red lips, river's lip): Twisted shells with red lips [...] ornamented the mantelpiece (Woolf VO: 9); They toiled along a tiny path on the river's lip (Lawrence SL: 285);

- ARTEFACT IS A HUMAN BODY (in $27 \%$ of text fragments): I love the telephone with its lip stretched to my whisper (Woolf W: 168), where telephone receiver is depicted as having lips (telephone with a lip);

- ABSTRACT PHENOMENON IS A HUMAN BODY (in $10 \%$ of text fragments): they had met in a naked extremity of hate (Lawrence SL: 353), where the feeling of hatred is eroticized by means of ascribing it the quality "nakedness" for emphasizing its frank and direct nature.

Unlike naturalized and romanticized narrativisation of the body in English modernism, eroticizing of the body in postmodernism prose takes place by means of accentuation of its "artificial" character and its "semiotization", accompanied on conceptual level by the metaphor HUMAN BODY IS AN ARTEFACT / ARTIFICIAL PHENOMENON / SIGN.

In literary interpretation of English postmodernism, the semiotic nature of the eroticized body is emphasized in conceptual metaphors HUMAN BODY IS A TEXT / MANUSCRIPT / BOOK / PALIMPSEST, that goes along with the general tendency of postmodernism to reality textualization (Дерріда 2001) and human body - in particular (Барт 1989). This tendency towards semiotization of eroticized body is lavishly observed in J.Winterson's "Written on the Body":

Written on the body is a secret code [...] the accumulations of a lifetime. The palimpsest is so heavily worked that the letters feel like Braille. I like to keep my body rolled up away from prying eyes. Never unfold too much, tell the whole story. I didn't know Louise would have reading hands (Winterson WB: 89 ).

Corporality acquires the qualities of a text, being metaphorically described as a surface on which the secret code (life experience of a character) is placed (written on the body is a secret code). The body 
getting the nature of a palimpsest with letters feeling like Braille, is kept rolled up, never unfolded in order not to tell the whole story.

In such imagery interpretation, the body's semiotic function is polymorphic: one lover's body is both the code itself and the surface for placing signs on it (a manuscript, a palimpsest), while the other lover's body is a decoder (translator, interpreter): Your hand prints are all over my body. You deciphered me and now I am plain to read. The message is a simple one, my love for you (ibid: 106); I will find a clue to you, I will be able to unravel you (ibid: 50). Conceptualization in terms of the metaphor SEX IS THE PROCESS OF ENCODING AND DECODING SIGNS is obvious in the following text fragment: She translated me into her own book (ibid: 89); Articulacy of fingers, the language of the deaf [...]. Who taught you to write in blood on my back? The pads of your fingers are printing blocks, you tap a message onto my skin, tap meaning into my body. Your morse code interferes with my heart beat (ibid: 89).

Linguistic markers of textual nature of eroticized body are nominations of types of codes (morse) code, language, letters, Braille, of means and result of encoding - write, print, tap message / meaning and their decoding - decipher, find a clue, unravel, translate, read.

According to the type of transformation of eroticized bodies in literary prose of English modernism and postmodernism different tendencies of narrativisation are observed. In modernistic vision eroticizing of the body takes place on the background of its "modification", accompanied by imagery conceptualization according to the model of characterization EROTICIZED BODY IS A MODIFIED BODY, while in postmodernistic narrative "deviation" of the body according to the conceptual model EROTICIZED BODY IS DEVIANT / PERVERSE BODY predominates.

The actualization of the narrative pattern "modification" implies transformation of the body with its transfer to another state that verbally takes place with the help of metamorphosis as a means of imagery formation and cognitively is based on the integration of analogous and converse means of conceptualization (Bielekhova 2002).

In literary texts of English modernism, the following three types of metamorphoses in imagery formation of eroticized body are singled out:

1) metaphorical changes of consistence of human body which can figuratively be in any possible physical state of a substance - being modified from solid to liquid one, the state of gas or plasma, it melts or dissolves. It usually happens under the influence of high temperature caused by the interaction of male and female bodies and implies conceptualization of female body by means of the metaphors HUMAN BODY IS ICE / AIR, of male body - HUMAN BODY IS FIRE: She melted under his touch (Lawrence LCL: 112); She was lighter than air, dissolving [...] with ecstasy (ibid: 147); His fire made her body melt (ibid: 214). Textual signals of this type of metamorphosis nominate transformations with the transfer to other state or acquiring new qualities - melt, become lighter than air, dissolve;

2) metamorphoses based on metaphorical conceptualization according to the model HUMAN BODY IS A NATURAL OBJECT, THAT IS BEING TRANSFORMED. It can be illustrated with the conceptual metaphor HUMAN BODY IS A FOREST THAT UNDERGOES CHANGES IN SPRING, where forest in the course of natural metamorphoses in spring is a metaphorical correlate of a female body: She was [...] like a forest soughing with the dim, glad moan of spring, moving into bud [...] she felt him and his child. His child was in all her veins, like a twilight (Lawrence LCL: 117); She was like a forest, humming inaudibly with myriad unfolding buds (ibid). Textual signals of narrative pattern "modification" in these text fragments are not only verbal markers of transformation of forest in spring (moving into bud, unfolding buds), but also spring, twilight as threshold symbols of transfer - spring as the beginning of new life cycle, twilight symbolizing prelude to a new cycle of being; 
3) the most complicated type of metamorphosis implies the change of roles of source and target domains, i.e. metaphorical conceptualization of HUMAN BODY as target-domain in terms of source-domain, where the latter is transformed into a target-domain (HUMAN BODY).

This type of metamorphosis is illustrated by the fragment of D.H. Lawrence's "Lady Chatterley's Lover", where the inversion of metaphorical correlates is observed - from water space (sea, ocean) as a correlate of a woman's body to a female corporality as a correlate of water space in its transformations, generalized by means of conceptual metaphor HUMAN BODY IS A WATER SPACE IN THE STATE OF TRANSFORMATIONS $\rightarrow$ CHANGING / MOVING WATER SPACE IS A PROCESS OF FEMALE NATURE BIRTH, e.g.:

she was like the sea, dark waves rising and heaving, [...] and she was Ocean rolling its dark, dumb mass. [...] far down inside her the deeps parted and rolled asunder, [...] the heavier the billows of her rolled away to some shore, uncovering her [...] further rolled the waves of herself away, leaving her, till in a soft, shuddering convulsion [...] she was born: a woman (Lawrence LCL: 152).

Textual signals of the vector of conceptualization EROTICIZED HUMAN BODY IS A WATER SPACE are comparisons and metaphors where the body is compared to the sea (she was like the sea) or the ocean (she was Ocean rolling its mass). At the same time the body of a woman in sexual intercourse is similar to an object moved by the sea waves until it turns out to be on the shore (the billows of her rolled away to some shore, uncovering her), that in imagery interpretation of the author symbolizes the birth of a woman (she was born: a woman).

This metamorphosis is based on converse type of mapping with the elements of parabolic one due to its similarity to the birth of Aphrodite from the depth of the sea. Such comparison is also enriched by the symbolic meaning of rough waters associated with female loins and womb. "Birth" symbolizes new psychology of a woman - free in openness of her feelings - granted to her by a beloved man.

The process of eroticizing the body in literary texts of English takes place by means of conceptual model of characterisation EROTICIZED BODY IS A DEVIANT / PERVERSE BODY. It is traced in many literary texts of English postmodernism (P. Ackroyd, J. Fowles, J. Winterson, F. Weldon, A. Burgess, I. Waugh, etc.). Deviant body experience includes psychopathologies of realization of libido in an unusual or untraditional way or choice of sexual object, that are called sexual deviations or perversions.

Perversions of psycho-physiology of the body as an instance of sexual deviation is observed in the text of F. Weldon's novel "Life and Loves of a She-devil", where Judge Bissop liked to beat his partner cruelly in sadistic sexual act: he subjected her to extreme sexual practices [...] nipped her nipples with his teeth (Weldon LLSD: 164), demonstrating passion for bondage and whips (ibid: 168), causing body damage to his lovers: bruises and abrasions (ibid: 176). At the same time his passion Polly Patch also tended to masochism, getting pleasure from painful sexual experience: The judge, finding a willing sexual partner in Polly [...] binding her hand and foot to the bed, beating her; only relief would be violent physical contact with her, some kind of sexual mauling (ibid: 171).

Among textual signals of narrative pattern "deviation" there are lexical units nominating acts of violence (binding, beating, sexual mauling, violent physical contact, nip), and the results of body damage (bruise, abrasion).

All in all in literary interpretation of corporality in English modernism imagery and symbolic means of nomination of the eroticized body dominate ( $92 \%$ ) compared to predominant quantity of denotative $(60 \%)$ and imagery means $(38 \%)$ in English postmodernism. It is explained by much more exposed narrativisation of eroticism and sexual relations in postmodernistic prose, usually done by means of direct nomination, while for the formation of a romanticized vision of eroticized body in English modernism the usage of allegoric and figurative means is characteristic. The range 
of cognitive mechanisms applied in the course of imagery interpretation of the eroticized body comprise analogous (metaphor, parabola), converse (metamorphosis) and associative (metonymy) conceptual tropes, demonstrating common principles of aesthetic thinking. On the verbal level in narrativisation of the body in English modernism quantitatively prevail local and localized (96\%), whereas global means of verbal signals dominate in postmodernism.

Socialized body as a means of verbalization and narrativisation of the conceptual metaphor HUMAN BODY IS AN OBJECT / RESULT OF SOCIETY IMPACT is constructed by means of ascribing it such qualities as "artificiality" and "semiotization" in terms of a conceptual pattern HUMAN BODY IS AN ARTIFCIAL PHENOMENON / ARTEFACT / SIGN, accompanied by actualization of the narrative pattern "socializing". Specific features of corporality vision in modernist and postmodernist literary texts are obvious in view of transformation of the body. Socialized body is constructed against the background of its narrative "deformation" in the analysed English modernism literary texts, which takes place in accordance with the conceptual metaphor SOCIALIZED BODY IS A DEFORMED BODY, and its "destruction" in the literary texts of English postmodernism according to the conceptual pattern SOCIALIZED BODY IS A RUINED BODY.

The narrative pattern "deformation" actualized in literary texts of English modernism to emphasize the ruining effect of society on a person in imagery plane is accompanied by nomination of integrity loss, changes in size, consistence of the body or its damage and painful bodily experience standing for psychological discomfort, emotional and mental suffering of a person in up-to-date society: She [...] stood alone [...] feeling herself suddenly shrivelled, aged, breastless, [...] out of her body and brain which now failed, since Lady Bruton [...] had not asked her (Woolf MD: 23). The abovementioned text fragment illustrates the conceptual metonymy DEFORMED BODY stands for DEPRESSED PERSON applied by V. Woolf to describe psychological state of Mrs. Dalloway rejected by society being not invited to the party. It is performed by means of description of her body as a deformed one - shrivelled, aged and even deprived of gender property - breastless.

Applying the image of a WAX FIGURE as a metaphorical correlate of a HUMAN BODY in the course of literary interpretation of socialized body, V. Woolf verbally designates the result of social factors impact as melting of certain parts of wax coat depending on life experience of a person: we were all different. The virginal wax that coats the spine melted in different patches for each of us (Woolf W: 241). With age this wax coat melts and drops off - that is the way a person wastes his/her body away in social surrounding: my waxen waistcoat melted, here one drop, there another (ibid: 237); It is not age, it is that a drop has fallen; another drop (ibid: 271), that accentuates human vulnerability to hard life experience in the society, that has a deforming effect both on his/her body and soul.

In literary texts of English postmodernism, socializing of the body takes place on the background of its "destruction" according to the conceptual pattern of characterization SOCIALIZED BODY IS A RUINED BODY.

Narrative pattern "destruction" accompanied by "semiotization" of the body by means of accentuation of its discursive nature is observed in P. Ackroyd's novel "Dan Leno and the Limehouse Golem" where the author applies to the conceptual metaphor HUMAN BODY IS A DISCOURSE while giving description of a murder:

Another female prostitute was found lying against the small white pyramid in front of the church of St Anne's. Her neck had been broken, and her head unnaturally turned so that she seemed to be staring just beyond the church itself; her tongue had been cut out and placed within her vagina, while her body itself was mutilated [...]. Upon the pyramid the word 'golem' had been traced in the blood of the dead woman (Ackroyd DLALG: 6). 
In the abovementioned text fragment the significant fact is a combination of verbal signs (the word 'golem' had been traced in the blood of the dead woman), with non-verbal, corporeal signs, i.e. pose, face expression, location and the way of positioning of the dead body and its fragments. In particular, the head turn and direction of eyes of the victim (she had been gazing at the workshop where the Analytical Engine waited to begin its life (ibid: 124) are a part of corporeal "message" which the murderer uses to "inform" of a real murderer. The murdered body as if "tells" who is to blame in crimes by means of pointing to the place of engineering the mechanism that as if deprives humans of their souls: Perhaps Analytical Engine was the true Limehouse Golem, draining away the life and spirit of those who approached it [...] digits and numbers were little chattering souls trapped in the mechanism, and its webs of iron no less than the web of mortality itself (ibid: 147). In such a way the dead body becomes a "narrative" instrument in a murderer's hands, "dwelling" on the nature of social fears concerning fast development of technologies in the $20^{\text {th }}$ century with attempts of creating artificial mind and other mechanisms aimed at substituting functions of a human as surrogate forms of life.

The body under power as a variety of a socialized body in literary texts of English postmodernism becomes the object of imagery and narrative interpretation under the influence of destructive events of the $20^{\text {th }}$ century. On the narrative level it is accompanied by actualization of a narrative pattern "destruction", on the conceptual - by the selection of natural phenomena, which are fragile, as metaphorical correlates for the body that implies conceptual metaphor HUMAN BODY IS A PLANT / INSECT, e.g.: 'I collect butterflies' 'Now you've collected me. You've pinned me in this little room and you can gloat over me [...] never let me fly away' (Fowles C: 42).

Gender aspect of socialized body interpretation demonstrates common and specific features of linguopoetics of English modernism and postmodernism. The common ones concern imagery representation of destructive processes of the body under the influence of masculinecentred society. It is accompanied by the conceptualization of a female body through the prism of natural phenomena while a male body acquires metaphorical correlates among artefacts as the products of civilization. Specific features are obvious in the poetics of postmodernism in view of eliminating gender body (as in J. Winterson's novels) or its complete deconstruction as in F. Weldon's "The Life and Loves of a She-Devil": We can reshape the body quite dramatically! (Weldon LLSD: 235), can use chip technology, microsurgery (ibid: 236).

All in all in literary interpretation of corporality in English modernism imagery means of nomination of the socialized body dominate (87\%) compared to predominant quantity of denotative $(62 \%)$ and imagery-symbolic means $(38 \%)$ in English postmodernism. Verbal level demonstrates common features as in narrativisation of the body in both English modernism and postmodernism global verbal signals (67 \% and $76 \%$ respectively) prevail quantitatively. Cognitive processes involved in the imagery interpretation of a socialized body embrace analogous and associative mechanisms and their combinations.

\section{Conclusions}

This study of linguistic aspects of corporality in literary texts of English modernism and postmodernism, marked by the introduction of the cognitive-semiotic approach to the field of linguopoetic research, enabled the interpretation of literary corporality as a linguopoetic category.

The results obtained are of practical significance for widening epistemic attainments of cognitive poetics due to the application of the cognitive-semiotic approach to the analysis of literary text as a polycode system, as well as for introducing a new cognitive-semiotic branch in linguopoetic research of corporality.

The methodology of cognitive-semiotic analysis applied to the study of corporality in literary texts of English modernism and postmodernism can be employed for the investigation of corporality as a linguopoetic category in literary texts of other epochs, written in other languages, of other types 
of texts, as well as be extended to other categories actualized in literary texts. I hope my generalizations concerning fictionalized body narrative patterns in literary texts of English modernism and postmodernism will be a contribution to cognitive poetics, literary text semiotics, and cognitive narratology and open up new perspectives for their further investigation in English and other languages.

\section{REFERENCES}

Alieva, T.M. (2010). Polisemantism somaticheskoy leksiki v raznosistemnyh jazykah [Polisemy of somatic vocabulary in languages of different types]. PhD Diss. Makhachkala. (in Russian).

Arkadiev, P.M., Kreidlin, G.Ye., Lietuchiy, A.B. (2008). Emioticheskaya kontseptualizatsija tela I jego chastei. I. Pryznak «Forma». [Semiotic conceptualization of human body and its parts.

I. Quality «Form»]. Voprosy jazikoznanija. № 6. P. 78-97 (in Russian).

Barthes, R. (1989). Izbrannyie raboty: Semiotika. Poetika. [Selected works: Semiotics. Poetics]. Moscow: Progress. (in Russian).

Bieliekhova, L. I. (2002). Slovesnyi poetychnyi obraz $v$ istoryko-typologichniy perspektyvi: lingvokognityvnyi aspekt (na materiali amerykanskoi poezii) [Verbal poetic image in historico-typological perspective: linguokognitive aspect (on the poetry of America writers)]. Kherson: Ailant. (in Ukrainian).

Bogumil, M. L. (1988). Joyce's use of synaesthsia: The intra- and inter-episodic recurrence of sensory impressions in Ulysses: Ph.D. diss. Ann Arbor: University of South Florida.

Bykhovskaya, I. M. (2000). "Homo somatikos»: aksiologija chelovecheskogo tela ["Homo somatikos»: axiology of human body]. Moscow: Editorial URSS. (in Russian).

CCT (1997). - Collins Concise Thesaurus / ed. A. Holmes, M. O’Neil, I. Brookes, E. Summers. Glasgow: Harper Collins.

Derrida, J. (2001). Struktura, znak i gra u dyskursi gumanitarnyh nauk. Slovo. Znak. Dyskurs: Antologija svitovoi literaturno-krytychnoi dumky XX stolittia. Lviv: Litopys. P. 617-632. (in Ukrainian).

DFEL. - Dictionary of Frequency of the English language. Retrieved from: www.wordfrequency.info.

Dirven, R., Verspoor, M. (2004). Cognitive Exploration of Language and Linguistics. Amsterdam: John Benjamins.

Gallagher, Sh. (2006). How the Body Shapes the Mind. Oxford: OUP.

Gudkov, D. B., Kovshova, M.L. (2007). Telesny kod russkoi kultury: materialy $k$ slovariu [Corporeal code of Russian culture: materials to the dictionary]. Moscow: Gnosis. (in Russian).

Gundorova, T. (2010). Symptomatyka «hvorogo tila» [Simptoms of «ill body»]. Krytyka. 2010. Is. 7-8 (153-154). P. 24-28. (in Ukrainian).

Frolova, S. V. (2000). Chelovecheskaya telesnost: ontologicheskije nachala i filosofskije osnovanija [Human corporality: onthological initials and philosophic grounds]: PhD Diss. Saratov. (in Russian).

Ibarretxe-Antuñano, I. (2002). MIND-AS-BODY as a cross-linguistic conceptual metaphor. Miscelánea. A Journal of English and American Studies. No 25. P. 93-119.

Khrabrova, G. M. (2001). Hudozhnya visija tilesnosti v epohu Vidrodzhennja: aksiologija, semantyka i providni modeli representatsii [Literary vision of corporality in the Renaissance period: axiology, semantics and main patterns of representation]. Scientific works. Philology. Literature studies. Mykolaiv: Petro Mohyla MSU. P. 86-90. (in Ukrainian).

Klevtsova, O. B. (2007). Kontsept «chelovek telesny»: kognitivnoje modelirovanie i perenosy [Concept «Homo corporalis»: cognitive modelling and transfers]: PhD Diss. Tumen: TSU. (in Russian).

Knyazeva, Ye. (2009). Telesnaja priroda soznanija [Corporeal nature of consciusness]. Телесность как эпистемологический феномен / ed. by I. A. Beskova. Moscow. P. 31-54. (in Russian). 
Koretskaya, L. F. (2006). Telesnost cheloveka kak objekt sotsiogumanitsrnogo poznanija [Human corporality as an object of socio-humanitarian comprehension]. Bulletin of Irkutsk state Academy of Economics. № 1 (46). P. 69-74. (in Russian).

Korotun, O. V. (2002). Obraz-kontsept «Vneshnij chelovek» v russkoj jazykovoj kartine mira [Image-concept «External human being»in Russian linguistic picture of the world]: PhD Diss. Omsk. (in Russian).

Kövecses, Z. (2002). Metaphor: A Practical Introduction. Oxford: Oxford University Press.

Krutkin, V. L. (1997). Telesnost cheloveka v ontologicheskom izmerenii [Human corporality in onthological vision]. Social sciences and the present. № 4. P. 143-151. (in Russian).

Kulichikhina, M. A. (2012). Telo i telesnost $v$ nemetskom romantizme: kontseptsii i obrazy [Body and corporality in German Romanticism: conceptions and images]: PhD Diss. Moscow. (in Russian).

Lakoff, G., Johnson, M. (1980). Metaphors We Live by. Chicago: University of Chicago Press.

Langacker, R. W. (1990). Concept, image, and symbol: The cognitive basis of grammar. Berlin and New York: Mouton de Gruter.

Marmaridou, S. (2011). The relevence of embodiment to lexical and collocational meaning: The case of prosopo 'face' in Modern Greek. Embodiment via body parts / ed. Z. Maalej \& N. Yu. Amsterdam: John Benjamins. P. 23-40.

Materynska, O. V. (2009). Typologiya naimenuvan chastyn tila [Typology of body parts nominations]. Donetsk. (in Ukrainian).

Merleau-Ponti, M. (1999). Fenomenologija vosprijatija [Phenomenology of perception]. Saint Petersbourg: Yuventa. (in Russian).

Mescheriakova, O. A. (2011). Semantyka pertseptsii $v$ aspekte hudozhestvennoi kognitsii I.A. Bunina [Semantics pf perception in the aspect of literary cognition of I.A. Bunin]: PhD Diss. Moscow. (in Russian).

Nasalevich, T. V. (2003). Portretnyi opys u riznyh typah tekstu [Portrait description in different types of texts]: PhD Diss. Odessa. (in Ukrainain).

Ostry, M. V. (2007). Problema telesnosti v zapadnom iskusstve XX veka: ontologicheskij aspekt [Problem of corporality in Western art of XX century]: PhD Diss. Samara. (in Russian).

Perminova, A. V. (2003). Vidtvorennia angliiskoi sensornoi leksyky $v$ ukrainskih virshovyh perekladah [Representation of English sensory lexicon in Ukrainian poetry translations]: PhD Diss. Kiev. (in Ukrainian).

Podoroga, V. A. (1995). Fenomenologija tela. Vedenije v filosofskuju antropologiju [Phenomenology of a human body. Introduction into philosophic antropology]. Moscow: Ad Marginem. (in Russian).

Poltarobatko, Ye. D. (2009). Kategorija telesnosti v akmeisticheskom diskurse [Category of corporality in acmeism discourse]: PhD Diss. Moscow. (in Russian).

Rosch, E. H. (1978). Principles of Categorization. Cognition and Categorization. Hillsdale, New York: Lawrence Erlbaum. P. 27-48.

Seryakova, I. I. (2012). Somatikon англомовних дискурсивних практик [Somaticon of Anglophone discursive practice]: Diss. of Doctor of Science. (in Russian).

Shteinbuk, F. M. (2006). Antropologichnist tilesnosti v tekstovyh strategijah suchasnoi literatury v konteksti vidnoshennja do vlasnogo tila [Anthropology of corporality in textual strategies of contemporary literature in the context of attitude to the own body]. Culture of the Black Sea peoples. № 92. P. 86-90. (in Ukrainan).

Shtokhman, L. M. (2008). Antropologija naratsii: stat, gender i seksualnist v romani J. Winterson «Tainopis ploti» [Antropology of narration: sex, gender and sexuality in J. Winterson's novel «Written on the Body»]. Studia methodologica: "Antropology of literature: communication, language, corporality». Vol. 25. Ternopil. P. 284-287. (in Ukrainian). 
Skachkov, A. Yu. (2007). Лінгвостилістичні особливості портретних описів у творах M. Коиюбинського [Linguostylistic features of portrait descriptions in M. Kotsubinsky's novels]: PhD Diss. Kharkiv. (in Ukrainian).

Soloschuk, L.V. (2006). Verbalni i neverbalni komponenty kominikatsii v anglomovnomu dyskursi [Verbal and non-verbal components of communication in Anglophone dicourse]. Kharkiv: Konstanta. (in Ukrainian).

Starostina, Yu. A. (2009). Kontsepty «zapah» i «krasota» v romane P. Suskinda «Parfumer. Istoria odnogo ubiytsy» [Concepts of «smell» and «beauty» in P.Suskind's novel «Perfume. The Story of a Murderer»]. Bulletin of Volgograd state university. Philology. № 7 (41). P. 164169. (in Russian).

Stetsiura, L. V. (2010). Kontseptosphera «organism cheloveka» v professionalnoi kartine mira medika [Domain «human organism» in the professional picture of the world of a medical worker]: PhD Diss. Cheliabinsk. (in Russian).

Tataru, L. V. (2007). Predstavlenie kontsepta «Telo cheloveka» v компоkompozitsionno-narrativnoi strukture modernistskogo teksta [Interpretation of the concept «Human body» in compositional and narrative structure of a modernist text]. Bulletin of SPbU. Philology, Eastern languages studies, journalism. Vol. 4 (P. II). P. 68-77. (in Russian).

Turaieva, Z. Ya. (1979). Kategorija vremeni. Vremja grammaticheskoye $i$ vremja hudozhestvennoje [Category of time. Grammatical and literary time]. Moscow: Vysshaja shkola. (in Russian).

Turner, M. (1998). The Literary Mind: The Origins of Thought and Language. Oxford: OUP.

Verbytska, O. (2009). Tilo jak tekst: semiotyka postmodernistychnogo rozuminnja [Human body as a text: semiotics of postmodernistic understanding]. Bulletin of Lviv University. Phylosophy. Is. 12. P. 85-91. (in Ukrainian).

Violi, P. (2010). How our bodies become us: Embodiment, semiosis and intersubjectivity. Journal of Cognitive Semiotics: The Intersubjectivity of Embodiment. Vol. 4. No. 1. P. 56-75.

Vorobyova, O. P. (1993). Lingvisticheskiye aspekty adresovannosti hudozhestvennogo teksta [Linguistic acpects of addressedness of a literary text]: Diss. of Doctor of Science. Moscow. (in Russian).

Vorobyova, O. P. (2012). Smak «shokoladu»: intermedialnist i emotsiinyi rezonans [Taste of «chocolate»: intermediality and emotional resonance]. Bulletin of Kiev National Linguistic University. Philology. 2012. Is. 15. № 1. P. 5-11. (in Ukrainian).

WTNIDEL (1993). - Webster's Third New International Dictionary of the English Language (Unabridged) / ed. Ph. Gove. Cologne: Konemann.

Yeliferova, M. V. (2007). Telesnost i metafora ploti v «Venetsianskom kuptse» [Corporality and metaphor of flesh in «Venetian Merchant»]. Shakespear studies VII. P. 45-55.

Zalevskaya, A. A. (2005). Korporealnaya semantika i integrativnyi podhod k jazyku [Corporeal semantics and integrative approach to a language]. Psycholinguistic studies. Word. Text. Moscow: Gnosis. P. 245-255. (in Russian).

Zamoiska, I. (2004). Struktura slovotvirnyh paradygm imennykiv na poznachennja vnutrishnih organiv liudyny [The structure of word-forming paradigms of nouns nominating internal organs of a human being]. Bulletin of Lviv university. Phylology. P. 1. Vol. 34. P. 153-158. (in Ukrainian).

Ziemke, T. (2003). What's that thing called embodiment? Proceedings of the 25th Annual Meeting of the Cognitive Science Society / ed. by R. Alterman, D. Kirsh. Mahwah, New York: Lawrence Erbaum. P. 1305-1310.

Zlatev, J. (2008). The co-evolution of intersubjectivty and bodily mimesis. The Shared Mind: Perspectives on Intersubjectivity / ed. J. Zlatev, T. Racine, C. Sinha, E. Itkonen. Amsterdam: Benjamins. P. 215-244. 


\section{DATA SOURCES}

Ackroyd DLLG. - Ackroyd, P. (1995). Dan Leno and the Limehouse Golem or The Trial of Elisabeth Cree. London: Minerva.

Ackroyd HHD. - Ackroyd, P. (1994). The House of Doctor Dee. London: Penguin Books.

Ackroyd L. - Ackroyd, P. (2003). London. A Biography. London: Anchor.

Fowles C. - Fowles, J. (1997). The Collector. London: Back Bay Books.

Fowles ET. - Fowles, J. (1999). The Ebony Tower. London: Back Bay Books.

Lawrence LCL. - Lawrence, D. H. (2011). Lady Chatterley's Lover. New York: Empire Books.

Lawrence PO. - Lawrence, D. H. (1995). The Prussian Officer. The Prussian Officer and Other Stories. London: Penguin Group. P. 1-21.

Lawrence FSG. - Lawrence, D. H. (1995). Fragment of Stained Glass. The Prussian Officer and Other Stories. London: Penguin Group. P. 88-98.

Lawrence EME. - Lawrence, D. H. (2011). England, My England. England, My England. New York: CreateSpace. P. 1-28.

Lawrence SL. - Lawrence, D. H. (2011). Sons and Lovers. New York: Empire Books.

Lodge T. - Lodge, D. (2002). Thinks. London: Penguin books.

Rushdie MC. - Rushdie, S. (2006). Midnight Children. London: Random House.

Weldon LLSD. - Weldon, F. (1993). The Life and Loves of She-Devil. London: Ballantine Books.

Winterson WB. - Winterson, J. (2001). Written on Body. London.

Woolf W. - Woolf, V. (2000). The Waves. London: Wordsworth Editions.

Woolf VO. - Woolf, V. (2011). Voyage Out. New York: CreateSpace.

Woolf MD. - Woolf, V. (2010). Mrs. Dalloway. A Room of One's Own. Houghton Mifflin.

Woolf LL. - Woolf, V. (2002). Lappin and Lapinova. A Haunted House and Other Short Stories.

Orlando: Mariner Books. P. 68-79.

Woolf TA. - Woolf, V. (2002). Together and Apart. A Haunted House and Other Short Stories. Orlando: Mariner Books. P. 136-144.

Iryna Galutskikh - PhD, Associate Professor of English Philology Chair at the Department of Foreign Philology of Zaporizhzhya National University, (66, Zhukovskogo st., Zaporizhzhya, Ukraine). E-mail: iryna.galutskikh@gmail.com. ORCID: 0000-0003-4263-942X. Google Scholar profile: https://scholar.google.com.ua/citations?user=pXWcVo4AAAAJ\&hl=ru

Ірина Анатоліївна Галуцьких - доктор філологічних наук, доцент кафедри англійської філології Запорізького національного університету, (66, вул. Жуковського, м. Запоріжжя, Україна). E-mail: iryna.galutskikh@gmail.com. ORCID: 0000-0003-4263-942X. Google Scholar profile: https://scholar.google.com.ua/citations?user=pXWcVo4AAAAJ\&hl=ru

Ирина Анатолиевна Галуцких - доктор филологических наук, доцент кафедры английской филологии Запорожского национального университета, (66, ул. Жуковского, г. Запорожье, Украина). E-mail: iryna.galutskikh@gmail.com. ORCID: 0000-0003-4263-942X. Google Scholar profile: https://scholar.google.com.ua/citations?user=pXWcVo4AAAAJ\&hl=ru 